\title{
Amino Acid Composition of the Cell-Proteins from Mesophilic, Thermofacultative and Thermophilic Actinomycetes
}

\author{
By R. CRAVERI, P. L. MANACHINI, F. ARAGOZZINI AND \\ C. MERENDI \\ Cattedra di Microbiologia Industriale, Università degli Studi, \\ 20133 Milano, Italy
}

(Received 23 June 1972; revised I I September 1972)

In previous papers (Craveri, Hill, Manachini \& Silvestri, I965; Craveri \& Manachini, 1966; Manachini, Craveri \& Craveri, I967) we reported some correlation between DNA base composition and the growth temperature requirements of actinomycetes. A few forms are truly thermophilic; they also possess DNA with a much lower guanine + cytosine content ( 44 to $55 \%$ GC) than the other forms ( 74 to $79 \% \mathrm{GC}$ ). Except for the high $\%$ GC $(72 \cdot 2 \%)$ reported by Yamaguchi ( 1967$)$ for a strain of Thermoactinomyces vulgaris, for which a new determination must be carried out, our findings are supported by the data of Evreinova, Tsaplina, Agre \& Davydova (1965), Tsyganov, Namestnikova \& Krasikova (1966), Tewfik \& Bradley (I967), Tsyganov \& Krasikova (1968) and Hopwood \& Wright (I972). Accordingly, on the basis of the protein genetic code, the protein amino acid composition of the thermophilic actinomycetes should present significant differences from other forms.

In the present study the cell-protein amino acid composition of eleven strains belonging to eight actinomycete genera with different $\% \mathrm{GC}$ and temperature requirements has been determined. All strains were grown by using a two-stage-submerged culture programme in $500 \mathrm{ml}$ flasks on a reciprocal shaker $(80 \mathrm{rev} . / \mathrm{min})$ and the same medium: meat extract (Oxoid), $3 \mathrm{~g}$; peptone (Difco), $3 \mathrm{~g}$; tryptone (Difco), $3 \mathrm{~g}$; yeast extract (Difco), $3 \mathrm{~g}$; unrefined maltose, $20 \mathrm{~g}$; tap water, I $1 ; \mathrm{pH} 7$; sterilization II $5{ }^{\circ} \mathrm{C}$ for $20 \mathrm{~min}$. The mesophilic strains were cultivated at $30^{\circ} \mathrm{C}$ for about 2 days in the second stage, the thermofacultative at $40{ }^{\circ} \mathrm{C}$ for about I day, and the thermophilic at $45^{\circ} \mathrm{C}$ for about $\mathrm{I} 5 \mathrm{~h}$, to produce a good mycelial growth without lysis. Mycelia from the second stage ( 10 to $20 \mathrm{~g}$ of wet mycelium each) were harvested by centrifugation, washed three times with distilled water and treated for 10 to 5 min with a Silverson L2R mechanical disintegrator (Silverson Machines' Ltd., Chesham, Buckinghamshire) or for 5 to Io min with an ultrasonic disintegrator (M.S.E. Ltd., Crawley, Sussex) at $20 \mathrm{kc} / \mathrm{s}$. After centrifugation ( $10000 \mathrm{~g} \times 30 \mathrm{~min}$ ), cell-proteins were precipitated from the supernatant with one volume of I0 \% TCA, collected by centrifugation and washed successively with methanol, methanol + ethyl ether (I:I, v/v) and ethyl ether. All operations were carried out at $5{ }^{\circ} \mathrm{C}$. The resulting protein preparations were dried under vacuum and samples of 5 to Io $\mathrm{mg}$ hydrolysed in $6 \mathrm{~N}-\mathrm{HCl}$ at $110^{\circ} \mathrm{C}$ for $24 \mathrm{~h}$ in vacuum-sealed vials, according to the procedure of Moore \& Stein (1963). The amino acid compositions were determined in an Optica automatic amino acid analyser (Optica, S.A.S., Milan, Italy), as described by Mondino (1967). Tryptophan was assayed after alkaline hydrolysis in $4 \mathrm{~N}-\mathrm{Ba}(\mathrm{OH})_{2}$ at $\mathrm{I}_{1} 0{ }^{\circ} \mathrm{C}$ for $50 \mathrm{~h}$ (Noltmann, Mahowald \& Kuby, I962) and cysteine + cystine after performic acid oxidation (Moore, I963) and hydrolysis in $6 \mathrm{~N}-\mathrm{HCl}$ at I I0 ${ }^{\circ} \mathrm{C}$ for $\mathrm{I} 8 \mathrm{~h}$.

The cell-protein amino acid composition of the actinomycetes studied are given in Table $\mathrm{I}$. There were differences, the most evident being the lower levels of alanine, proline and 


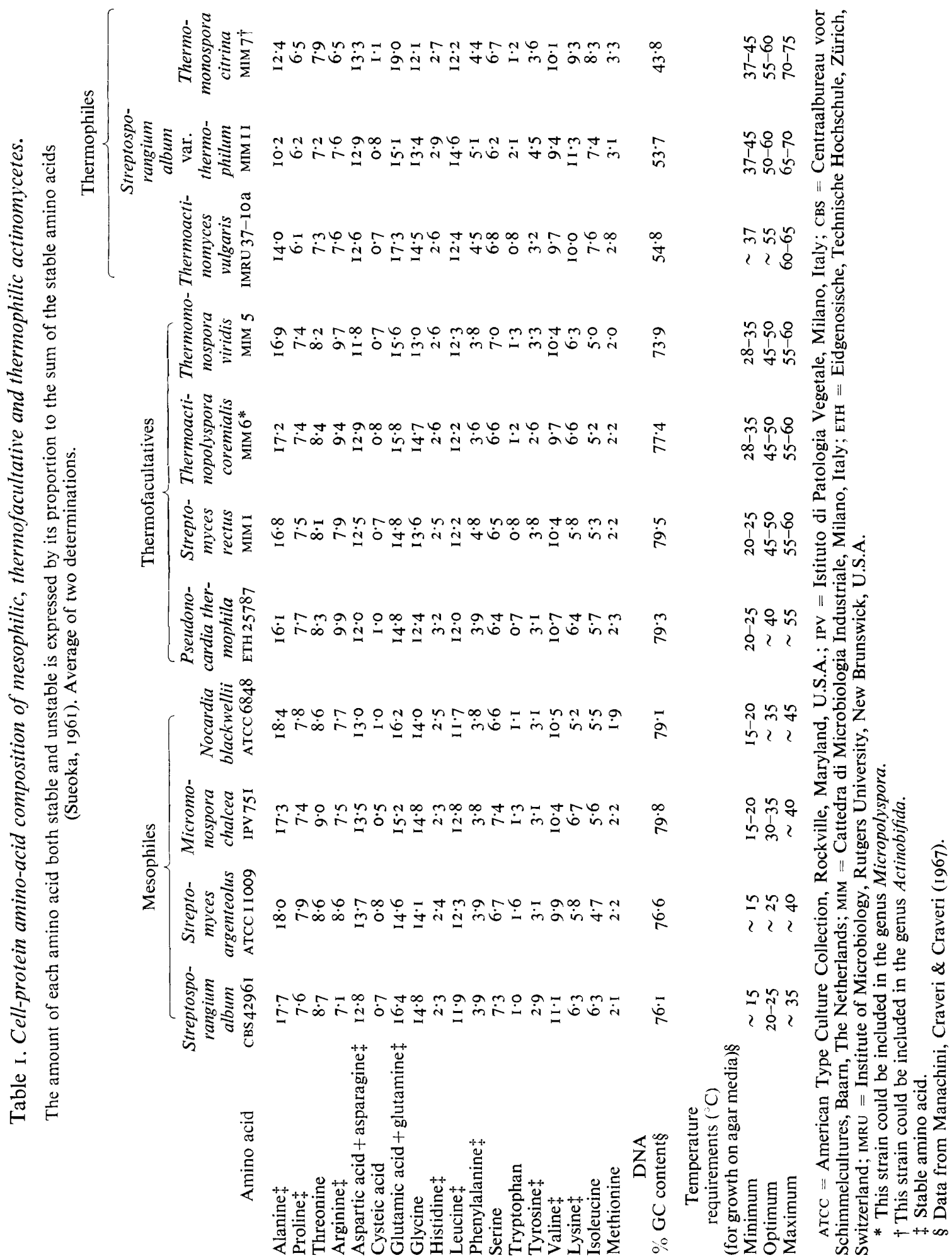


threonine and the higher levels of lysine, isoleucine and methionine shown by the true thermophilic strains when compared with both mesophilic and thermofacultative forms of actinomycetes. These differences in protein amino acid composition reflect the DNA base ratio engendered by the genetic code (Sueoka, 1961; Nirenberg et al. 1963; Speyer et al. 1963; Cooney \& Bradley, 1965).

The protein amino acid composition of actinomycetes thus indicates another differential characteristic which emphasizes, within this group, the distinction between true thermophilic forms on one hand and mesophilic or thermofacultative forms on the other. We also believe that the apparent evolutionary paradox exhibited by the thermophilic actinomycetes, namely their phenotypic similarity, yet widely different GC content of DNA when compared with other forms, which has already been considered by Craveri et al. (I965), Rosypal \& Rosypalova (1966), Gause (1968), De Ley (1970), Prauser (1970), Silvestri (1970) and Lechevalier, Lechevalier \& Gerber (197I), has been reinforced.

\section{REFERENCES}

CoOney, W. J. \& Bradeey, S. G. (1965). Amino acid composition of the cell-proteins from streptomycetes and myxobacters. Biochimica et biophysica acta 100, 594-595.

Craveri, R., Hill, L. R., Manachini, P. L. \& Silvestri, L. G. (1965). Deoxyribonucleic acid base compositions among thermophilic actinomycetes: the occurrence of two strains with low GC content. Journal of General Microbiology 4r, 335-339.

Craveri, R., Manachini, P. L. (1966). Contenuto GC del DNA di Streptomyces argenteolus e di Thermoactinomyces vulgaris colivati a diverse temperature. Annali di microbiologia 16, I-3.

DE LEY, J. (1970). Molecular techniques and applications in bacterial taxonomy. In The Actinomycetales, Jena International Symposium on Taxonomy, 1968, pp. 317-328. Edited by H. Prauser. Jena: Gustav Fisher Verlag.

Evreinova, T. N., Tsaplina, I. A., Agre, M. S. \& Davydova, I. M. (1965). Effect of temperature on nucleic acids of the thermophilic and mesophilic variants of Micromonospora vulgaris. Mikrobiologiya 34, $4 \mathrm{II}-4 \mathrm{I} 7$.

Gause, G. F. (1968). Alterations of DNA base composition in bacteria. In Progress in Nucleic Acid Research and Molecular Biology, vol. 8, pp. 49-70. Edited by S. Davidson and W. Cohn. New York: Academic Press.

HopwOod, D. A. \& WRIGHT, H. M. (1972). Transformations in Thermoactinomyces vulgaris. Journal of General Microbiology 7r, 383-398.

Lechevalier, H. A., Lechevalier, M. P. \& Gerber, N. N. (I971). Chemical composition as a criterion in the classification of actinomycetes. In Advances in Applied Microbiology, vol. 14, pp. 47-72. Edited by D. Perlman. New York: Academic Press.

Manachini, P. L., Craveri, A. \& Craveri, R. (1967). Contenuto GC del DNA di attinomiceti mesofili, termofacoltativi e termofili. Atti XIV ${ }^{\circ}$ Congresso della Società Italiana di Microbiologia 2, 13-22.

Mondino, A. (1967). A new system of automatic amino acid analysis. Journal of Chromatography 30, 100-1 12.

Moore, S. (1963). On the determination of cystine as cysteic acid. Journal of Biological Chemistry 238, 235-237.

Moore, S. \& Stein, W. H. (1963). Chromatographic determination of amino acids by the use of automatic recording equipment. In Methods in Enzymology, vol. 6. Edited by S. P. Colowick and N. O. Kaplan. London: Academic Press.

Nirenberg, M. W., Jones, O. W., Leder, P., Clark, B. F. C., Sly, W. S. \& PestKa, S. (I963). On the coding of genetic information. Cold Spring Harbor Symposia on Quantitative Biology 28, 549-557.

Noltmann, E. A., Mahowald, T. A. \& Kuby, S. A. (I962). Studies on adenosine triphosphate transphosphorylase. Journal of Biological Chemistry 237, $1146-1154$.

Prauser, H. (1970). Characters and genera arrangement in the Actinomycetales. In The Actinomycetales Jena International Symposium on Taxonomy, 1968, pp. 407-418. Edited by H. Prauser. Jena: Gustav Fisher Verlag.

Rosypal, S. \& Rosypalova, A. (1966). Genetic, phylogenetic and taxonomic relationships among bacteria as determined by their deoxyribonucleic acid base composition. Folia biologia, Abstracts of Faculty of Science of Brno 14, I-9I. 
SiLVESTRI, L. G. (1970). The evolution of the thermophilic Actinomycetales: an apparent evolutionary paradox. In The Actinomycetales. Jena International Symposium on Taxonomy, 1968, pp. 239-243. Edited by H. Prauser. Jena: Gustav Fisher Verlag.

Speyer, J. F., Lengyel, P., Basilio, C., Wahba, A. J., Gardner, R. S. \& Ochoa, S. (1963). Synthetic polynucleotides and the amino acid code. Cold Spring Harbor Symposia on Quantitative Biology 28, 559-567.

SuEOKA, N. (196I). Correlation between base composition of deoxyribonucleic acid and amino acid composition of protein. Proceedings of the National Academy of Sciences of the United States of America 47, II I I-I I 49.

TewFiK, E. M. \& BRAdley, S. G. (1967). Characterization of deoxyribonucleic acid from streptomycetes and nocardiae. Journal of Bacteriology 94, 1994-2000.

Tsyganov, V. A. \& Krasikova, N. V. (1968). DNA composition as a taxonomic criterion of actinomycetes. Mikrobiologiya 37, 969-971.

Tsyganov, V. A., Namestnikova, V. P. \& Krasikova, N. V. (I966). Composition of deoxyribonucleic acids in members of different genera of actinomycetes. Mikrobiologiya 35, 92-95.

YAMAGUCHI, T. (I967). Similarity in DNA of various morphologically distinct actinomycetes. Journal of General and Applied Microbiology 13, 63-71. 